\section{Stars of biology}

\section{Dai Roberts}

A Functional Biology of Echinoderms. By John Lawrence. Croom Helm, London/ Johns Hopkins University Press, Baltimore: 1987. Pp340. £40, \$56.50

Pentamery, the water vascular system and a distinctive skeleton mark echinoderms apart from all other animal phyla. The nature and origin of these features remain puzzles for all students of the group, and for biologists more widely. By bringing together earlier comparative structural information and the more recent, exciting developments in echinoderm biology, John Lawrence brings a new perspective to these problems.

Without labouring details of structure, which are assumed and summarized in an invaluable appendix, Lawrence rapidly introduces the reader to present interpretations of the interrelationships and

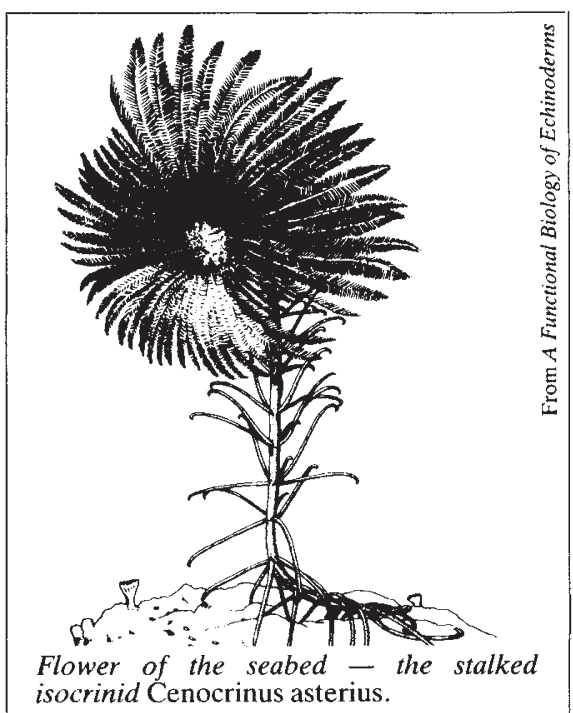

diversity of echinoderm groups. Chapters deal with nutrient acquisition, maintenance and reproduction, central features of modern functional biology.

Details of feeding processes in different taxa form the basis for a comparative study of feeding efficiencies. Lawrence shows how enhanced feeding by structural elevation of the feeding arms of stalked crinoids is paralleled by functional elevation in the stalkless comatulids. Similarly, the orientation of suspension-feeding structures and intraspecific aggregations, which are particularly dense in some groups, may enhance particle capture.

The great adaptability of animal structure is particularly well illustrated by echinoderms, which show repeated adjustment of a relatively narrow suite of characters to diverse functions. Tube feet may be used for respiration and feeding as well as for locomotion; echinoid spines may have roles in locomotion and feeding as well as for defence; mutable collagenous tissue may maintain feeding posture in crinoids or provide defensive rigidity in holothuroids. The enigma of the apparent absence of a circulation based on a single system common to all groups is probably yet another aspect of this structural adaptability, with different systems taking on a circulatory role in different groups. Lawrence documents many of these aspects of echinoderm biology, but more

\section{Drilling for victory}

\section{Joe Cann}

The Superdeep Well of the Kola Peninsula. Edited by Ye. A. Kozlovsky. SpringerVerlag: 1987. Pp.558. DM248.

IN May 1970, the SG-3 borehole was spudded into the Precambrian crust of the Kola Peninsula in Arctic Russia in an ambitious attempt to drill through thick Proterozoic sedimentary and volcanic rocks, to cross the Conrad discontinuity in the Earth's continental crust and to sample the lower crust in place. After ten rigyears of drilling, using two rigs, a total depth of $11.5 \mathrm{~km}$ had been reached when this book was published in Russian in 1984 , and further penetration was planned.

Here we have, translated into English, a full account of both the science and the technology of the project. It was both a great success and a mild failure - a failure because the Conrad discontinuity did not appear as expected. This was not surprising because over the past ten years evidence has become stronger and stronger that the Conrad was simply an artefact of the seismic processing methods used in classic seismic studies, and never did exist. The graphic proof comes from the log of this hole, and down with the Conrad discontinuity clatters the cumbersome apparatus of Sial and Sima, of granitic and basaltic layers in the continental crust, of the now extinct idea that oceanic crust continued beneath the continents. So even in failure the project had positive virtues.

What about its successes? First, there is the mere fact of drilling such a hole. Part 3 of the book discusses the drilling technology used and the problems that had to be overcome as the hole went deeper and deeper into rock more and more stressed by the overlying load. Turbo drills were deployed and in turn allowed use of light alloy drill pipe. High-temperature drilling muds were developed. Problems of rock fracturing became more intense. The discussion here is very detailed and most instructive, especially for those of us involved with scientific drilling elsewhere.

Part 2 is concerned with downhole logging of the sequence and with laboratory physical studies, and Part 1 with the importantly assesses them in terms of their costs and benefits.

The illustrations are good and the writing clear, and with over 600 references the book puts the available information into a helpful perspective. It will be an important resource work for students of echinoderms for the next decade.

Dai Roberts is a Senior Lecturer in the Department of Biology, The Queen's University, Belfast BT7 INN, UK.

geological aspects of the drilling. In places the usual profound irritations of Russian texts emerge. Nowhere, for example, in the section on geothermal measurements, is any table or figure of temperature with depth given - I still do not know the temperature at the bottom of the hole. Nor, in the section on seismic velocity logs, is there any scale on the numerous plots of $V_{\mathrm{p}}$ and $V_{\mathrm{s}}$ downhole, though here you do have a table to guess from. Sloppiness? Lack of concern for the reader? Or is there some profound necessity in keeping such information entirely obscure?

Most exciting of all of the results reported during the drilling of the well were that water flowed into the hole deep in the section, and hydrocarbons were found at depth in the gneisses. There is good reason to believe that the lower continental crust should be both dry and free of hydrocarbons, and I turned to the chapters on organics and water with great interest.

Unfortunately, both phenomena are not well documented. There were clearly problems in sampling fluids from the wells, because a formation tester could not be deployed deep in the section, but the lack of detail in the accounts does not allow a judgement of just how good or bad the samples were, or how liable to contamination. In the end I felt mildly baffled again by Russian obscurity. So the book is patchy - in places fascinating, in others irritating - but it documents what must be considered a spectacular achievement.

Joe Cann is a Professor in the Department of Geology, University of Newcastle upon Tyne, Newcastle upon Tyne NEI 7RU, UK.

\section{New in paperback}

- The Mind of a Mnemonist by A.R. Luria. Publisher is Harvard University Press, Price is $\$ 7.95, £ 6.25$.

- The Beginnings of the Nobel Institution by Elisabeth Crawford. Publisher is Cambridge University Press, price is $£ 9.95, \$ 16.95$. For review see Nature 314, 619 (1985).

- The Search for Solutions by Horace Freeland Judson. Publisher is Johns Hopkins University Press, price is $\$ 10.95, £ 6.65$.

- Actual Minds, Possible Worlds by Jerome Bruner. Publisher is Harvard University Press, price is $\$ 7.95, £ 6.50$.

- The Physicists: The History of a Scientific Community in Modern America by Daniel J. Kevles. Publisher is Harvard University Press, price is $\$ 12.95, £ 10.25$. 